\title{
Management Accounting Practice in Nepalese Commercial Banks
}

\author{
Chitra Bahadur Karki \\ Lecturer \\ Faculty of Management, Mahendra Multiple Campus, Dharan \\ Tribhuvan University, Nepal \\ Email: chitra.karki@mahmc.tu.edu.np \\ DOI: https://doi.org/10.3126/jom.v4i1.38661
}

\begin{abstract}
The paper aims to analyze the management accounting practice in Nepalese commercial banks. Primary data have been collected by using interview method and structured questionnaire. The accounting and audit department staff in the sample banks were served with questionnaires. The descriptive survey research has been utilized in this research. The study employed the simple percentage and simple average to analyze the research questions. A sample of six numbers Nepalese commercial banks has been considered with convenience sampling technique. The study found that various management accounting tools are in practice in Nepalese commercial banks and maximum Nepalese commercial banks use more than one management accounting tools. In addition, management accounting is important to Nepalese commercial banks' management for planning, evaluating, controlling and decision making and there are various problems in practicing management accounting tools in Nepalese commercial banks, such as lack of expertise, lack of information about tools, lack of top management's committee, accounting provisions of NRB, tax law compliances, high cost and so on.
\end{abstract}

Keywords: management accounting, commercial bank, management accounting tool, percentage, Nepal

\section{Introduction}

\section{Background}

Management Accounting refers to the application of professional knowledge, techniques and concept in preparing the accounting information with the help of financial accounting and cost accounting, which helps the management of the organization in the formulating plans and policies, controlling the operations of the 
organization, decision making, optimizing the use of resources, disclosure to management and safeguarding assets. The management accounting is based on financial accounting and cost accounting.

In current, there is a lot of competition among commercial banks in developed as well as developing countries. "Nepalese commercial banks are greatly suffering from limited resources, particularly the capital, technical knowledge, poor manpower, improper planning, ineffective information and controlling system, ineffective implementation of policies, political instability", (Gnawali 2017, p. 72). The owners of commercial banks want to go not only to the market but also to achieve higher position in the market. The responsibility of the commercial banks' director is important to achieve higher position in the market by taking right decision at right time. Management accounting tasks are very important to make right decision. Therefore, management accounting practices (MAP) are very essential to success for the commercial banks. Management Accounting Practices includes cost practices, budgeting, and information for decision making, strategic analysis and performance analysis. By using those practices, commercial banks make plans to get success in the dynamic market.

Various management accounting tools and techniques are in practice in Nepalese commercial banks to carry out planning, controlling and decision-making function. This study focuses the present practice of management accounting tools in the Nepalese commercial banks by taking some management accounting tools.

\section{Research Problems}

The focus of this study is to find out the present management accounting practices in Nepalese Commercial Banks by taking six listed commercial bank. The specific problems are as follows:

- What is the extent of the use of management accounting system in Nepalese Commercial Banks?

- What are the roles of management accounting in Nepalese Commercial Banks' management?

- What are the problems faced by Nepalese commercial banks in practicing management accounting tools?

\section{Research Objectives}


The general objective of the study is to analyze the present management accounting practices in Nepalese Commercial Banks. The specific objectives of the study are as follows:

- To identify the extent of the use of management accounting tools in Nepalese commercial banks.

- To evaluate the roles of management accounting in Nepalese commercial banks' management.

- To examine the problems faced by commercial banks in Nepal in practicing management accounting tools.

\section{Rationale of the Study}

The significance of this study is to identify, analyze and interpret the management accounting practice in Nepalese commercial banks. This study will also help bankers to use suitable management account tools. Other significances of this research article are as follows:

- This study will be useful to identify the suitable management accounting tools for Nepalese commercial banks.

- Similarly, this study will be useful for new researchers to learn more about the management accounting practice in Nepalese commercial banks.

\section{Limitations of the Study}

The study is limited to the following constraints:

- The study focuses the practice of management accounting only.

- The study depends on the commercial banks only.

- Only six commercial banks are taken as sample.

- Few management accounting tools only are taken in this study.

\section{Literatures Review}

This section presents the review of related literature in order to establish a basis for the investigation of the management accounting practice in Nepalese commercial banks. The review covered previous empirical studies conducted in various countries on this subject.

Gnawali (2018) focused his study to analyze accounting for management practices in Nepalese Commercial Banks. The objective of this study was to analyze the 
management accounting systems practices in Nepalese Commercial Banks. A descriptive and analytical research design has been employed in this research. There were 31 banks at the time of the study. A sample of 367 numbers of employees has been considered with convenience sampling technique. There were one set of questionnaires designed for the purpose of data collection from the respondents. At the outset; the independent variables of Management Accounting System include Budgeting \& Planning, Controlling \& Reporting, Decision support system, Costing system and Performance Evaluation. This study found that the Nepalese commercial banks have adopted management accounting practices that has increased the organizational performance.

Ashfaq, Younas, Usman \& Hanif (2014) conducted a research on the traditional Vs. contemporary management accounting practices and its role and usage across business life cycle stages. The objective of this study iwas to evaluate the management accounting practices that has been used in service sector of Pakistan. The data was collected through adapted questionnaire regarding management accounting practices and its level of usage by taking 90 target listed services companies. The unit of analysis was company and the responses were analyzed through descriptive statistics. This study found that, management accounting practices are more complicated as the companies move from growth to maturity stage and traditional management accounting practices still have the highest level in financial sector of Pakistan based on its importance \& usage.

Kingsley \& Omoghene (2018) carried out a research on management accounting information and fraud control measures in commercial banks. The objective of this research was to find out the influence of management accounting information on fraud control measures in Nigeria. The descriptive survey research was utilized in this research and the data was collected using interview method and structured questionnaire in this research. The Simple Percentage and Standard Deviation were used to analyze the research questions and Chi-square method was used to test the hypotheses in this research. Finding of this research is that, accurate management accounting information, fraud detection and fraud prevention are effective fraud control measures in the accounting and audit department of commercial banks in Nigeria

Russo (2014) conducted a study on role and importance of managerial accounting in to banking sector. The general objective of this study was to present the factors that confirm the need of managerial accounting for commercial bank and to 
define the benefits that may result from this. This research found that implementation of management accounting in banks is important to understand who, what brings profit or loss for bank, to make new system for supporting management decisions to make a foundation for effective planning and budgeting and to improve the ways of employees rewarding, assessing the contribution of each department to develop commercial bank.

Gnawali (20017) conducted a research on management accounting system practice in Nepalese commercial banks. Main objective of this research was to analyze the management accounting system tools practices and its roles in Nepalese Commercial Banks. Both primary and secondary sources of data have been used in this study and survey method is used for collecting primary data. This study is based on the descriptive research design. This research found that the perceptions of top management representative of commercial banks in Nepal perceived management accounting system tools as significant in their banking system and have also used these tools to increase their performance.

Kechema et al. (2019) carried out a research to examine the Barriers of accounting information system practice on the commercial banks. The objective of this research was to assess the accounting information systems practice of commercial banks of Ethiopia Bale-Robe branches. In this research Primary data were obtained through interviews and questionnaires to judgmentally selected employees from the branch. The cross-sectional was used and manipulated both descriptive and inferential statistics were employed in the study. Five sub branches selected as samples of population by convenience sampling method. Finding of this research is that accounting information system (AIS) become one of the most critical system to the capturing, processing, storing and distribution information. AIS must focus on critical factor to minimize the failure effects by create or collect, design, develop, and operate for bank and consumers in their work activities and managing the entire quality of commercial bank of Ethiopia in AIS practices.

\section{Research Gap}

Although many research works related to management accounting practice in commercial banks are found in the literature, very few research papers are found related to management accounting practice in commercial banks in the Nepalese context and there is still lack of latest research and article in the Nepalese context. This research is related to Nepalese context by taking latest data, so this research will help to fill research gap. 


\section{Research Methods and Materials}

The study examined the management accounting practice in Nepalese commercial banks using primary data which are collected using interview method and structured questionnaire. The accounting and audit department staff in the sample banks were served with questionnaires. Other necessary information related to this study has also been collected from the help of friends and phone no. of the banks. The descriptive survey research has been utilized in this research. All the commercial banks of Nepal are considered as the total population and six commercial banks i.e. Himalayan bank ltd.(HBL), Prabhu Bank ltd.(PBL), Standard chartered bank ltd.(SCBL),Nepal Bangladesh bank ltd.(NBBL),Everest bank ltd.(EBL) and State bank of India bank Itd.(SBIBL) are taken as sample. The study employed the Simple Percentage and simple average to analyze the research questions.

\section{Model}

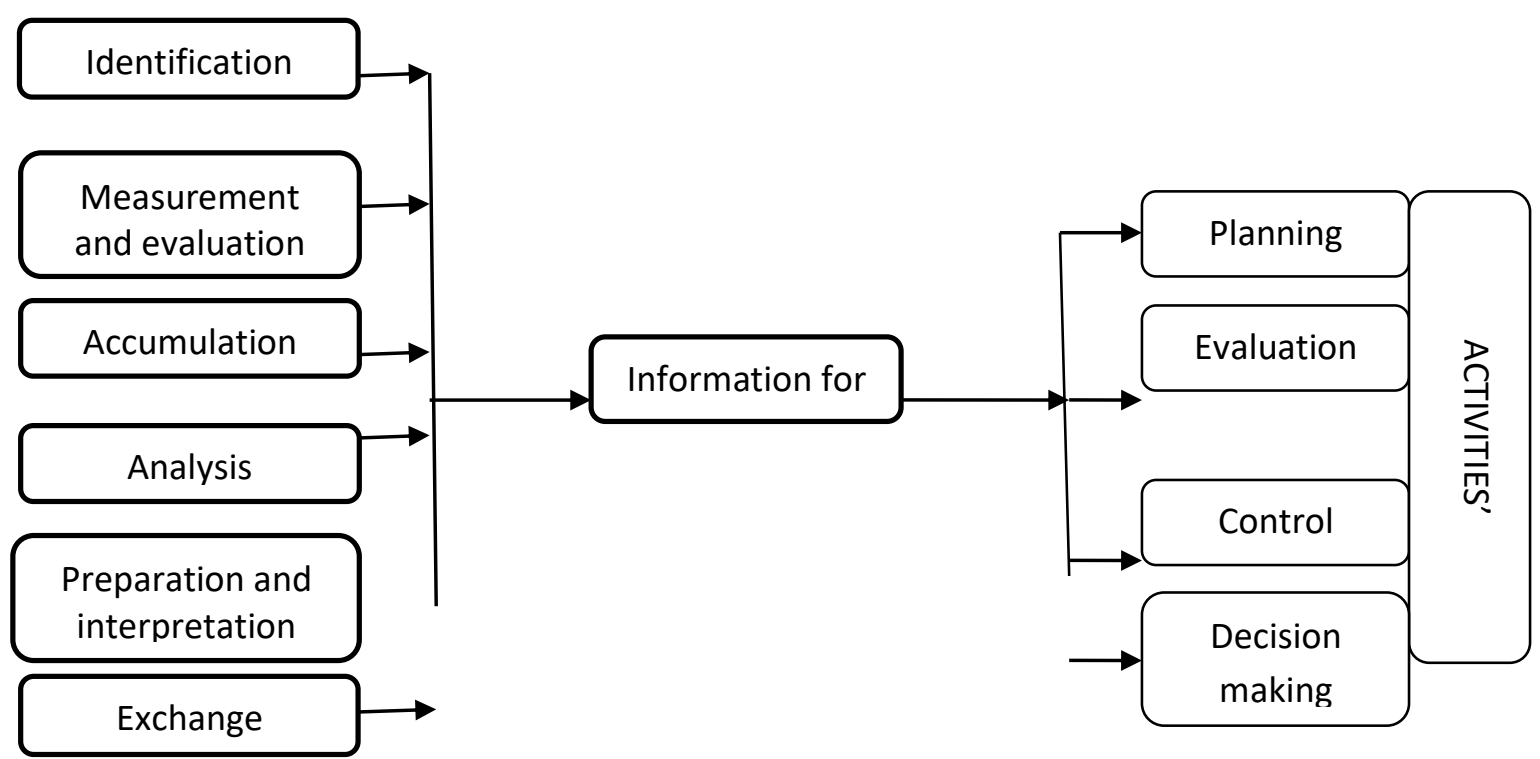

\section{Results and Discussion}

\section{Data Presentation}

The main objective of this study is to examine the present practice of management accounting tools and techniques in Nepalese commercial banks and there are some specific objectives also. For achieving those objectives, this chapter includes 
the presentation, analysis and interpretation of data. To complete this study necessary tables are presented below according to subject matter of questions.

\section{Table 1}

Analysis of Management Accounting Tools Practice

\begin{tabular}{clccc}
\hline S.N. & Management Accounting Tools & $\begin{array}{c}\text { No. of Sample } \\
\text { Banks }\end{array}$ & $\begin{array}{c}\text { No. of Practicing } \\
\text { Banks }\end{array}$ & $(\%)$ \\
\hline 1 & $\begin{array}{l}\text { Cost segregation in to fixed and } \\
\text { variable }\end{array}$ & 6 & 2 & 33 \\
2 & Responsibility accounting & 6 & 2 & 33 \\
3 & Standard costing & 6 & 0 & - \\
4 & Cash flow statement & 6 & 4 & 67 \\
5 & Break even analysis & 6 & 4 & 67 \\
6 & Pricing decision & 6 & 2 & 33 \\
7 & Activity based budgeting & 6 & 4 & 67 \\
8 & Zero based budgeting & 6 & 1 & 12 \\
9 & Capital budgeting & 6 & 4 & 67 \\
10 & Ratio analysis & 6 & 6 & 100 \\
\hline
\end{tabular}

Note. Appendix- A.

From the table 1 it is found that 33\% Nepalese commercial banks use cost segregation in to fixed and variable, responsibility accounting and pricing decision. $67 \%$ of them use cash flow statement, break even analysis. activity based budgeting and capital budgeting. $12 \%$ of them use zero based budgeting. $100 \%$ of them use ratio analysis and no one of them use standard costing.

\section{Table 2}

No. of Nepalese Com. Banks Practicing One or More Management Accounting Tools.

\begin{tabular}{ccc}
\hline No. of management accounting tools (x) & No. banks (f) & Fx \\
\hline 1 & 0 & 0 \\
2 & 0 & 0 \\
3 & 2 & 6
\end{tabular}




\begin{tabular}{ccc}
4 & 1 & 4 \\
5 & 1 & 5 \\
6 & 1 & 6 \\
7 & 0 & 0 \\
8 & 1 & 8 \\
9 & 0 & 0 \\
10 & 0 & 0 \\
\hline & $\mathrm{N}=6$ & $\Sigma \mathrm{fx}=29$ \\
\hline
\end{tabular}

Note. Appendix A.

Average no. of management accounting tools per bank $=\frac{\Sigma f x}{N}=29 / 6=4.83$ i.e. 5 (App.)

From table 2 it is found that five management accounting tools are used in a bank on an average. Similarly, it is shows that two banks use more than the average no. of management accounting tools, three banks use less than the average number of management accounting tools and one bank uses exactly five management accounting tools.

\section{Table 3}

Base for Budget Preparation in Commercial Banks in Nepal

\begin{tabular}{clccc}
\hline S.N. & \multicolumn{1}{c}{ Base for budget } & $\begin{array}{c}\text { No. of sample } \\
\text { banks }\end{array}$ & $\begin{array}{c}\text { No. of practicing } \\
\text { banks }\end{array}$ & $\%$ \\
\hline 1 & Actual expenses of previous year & 6 & 5 & 83 \\
2 & Past budget & 6 & 2 & 33 \\
3 & Activity based budgeting & 6 & 4 & 67 \\
4 & Zero based budgeting & 6 & 1 & 17 \\
5 & Other (if any) & 6 & - & - \\
\hline
\end{tabular}

Note. Appendix B.

From table 3 it is found that $83 \%$ of commercial banks of Nepal prepare their budget on the basis of actual expenses of previous year, 33\% commercial banks prepare budget taking past budget ,67\% commercial banks prepare budget taking activity based budgeting and $17 \%$ banks prepare budget taking zero based budgeting. 


\section{Table 4}

Types of Budget Practiced by Nepalese Commercial Banks

\begin{tabular}{clccc}
\hline S.N. & \multicolumn{1}{c}{ Types of budget } & No. of sample banks & $\begin{array}{c}\text { No, of practicing } \\
\text { banks }\end{array}$ & $\%$ \\
\hline 1 & Cash budget & 6 & - & - \\
2 & Operational budget only & 6 & 1 & 17 \\
3 & Overall master budget & 6 & 3 & 50 \\
4 & Long term budget & 6 & - & - \\
5 & Annual budget & 6 & 5 & 83 \\
6 & Others & 6 & - & - \\
\hline
\end{tabular}

Note. Appendix C

In table 4 , it is found that $17 \%$ of commercial banks practice operational budget, $50 \%$ of them practice overall master budget and nearly $83 \%$ of them practice annual budget.

\section{Table 5}

Capital Budgeting Techniques Practiced by Nepalese Commercial Banks

\begin{tabular}{clccc}
\hline S.N. & Capital budgeting techniques & $\begin{array}{c}\text { No. of sample } \\
\text { banks }\end{array}$ & $\begin{array}{c}\text { No. of practicing } \\
\text { banks }\end{array}$ & $\%$ \\
\hline 1 & Payback period (PBP) & 6 & 2 & 33 \\
2 & Average rate of return (ARR) & 6 & - & - \\
3 & Net present value (NPV) & 6 & 4 & 67 \\
4 & Internal rate of return (IRR) & 6 & 1 & 17 \\
5 & Profitability index (PI) & 6 & - & - \\
6 & Modified internal rate of & 6 & - & - \\
7 & return & & & 17 \\
\hline
\end{tabular}

Note. Appendix D. 
From table 5 it is found that $67 \%$ of Nepalese commercial banks use NPV, $33 \%$ of them use PBP, $17 \%$ of them use IRR and $17 \%$ of them use other technique for capital budgeting purpose.

\section{Discussion}

Various management accounting tools are in practice in Nepalese commercial banks. Maximum banks (100\%) use ratio analysis, minimum banks (17\%) use zero based budgeting, and normally (67\%) banks use cash flow statement, break even analysis activity based budgeting and capital budgeting. Maximum Nepalese commercial banks use more than one management accounting tools. Per Nepalese commercial bank uses five management accounting tools on an average. Nepalese commercial banks prepare budget using various basis. Maximum commercial banks (83\%) prepare budget on the basis of actual expenses of previous year and minimum banks (17\%) prepare budget on the basis of zero based budgeting. Nepalese commercial banks practice various types of budgets. Maximum banks (83\%) practice annual budget, minimum banks (17\%) practice operational budget only, 50\% banks practice overall master budget and no one practice cash budget, long term budget and other. Maximum Nepalese commercial banks practice capital budgeting technique. Out of various capital budgeting techniques, maximum banks (67\%) practice net present value (NPV) technique, minimum banks (17\%) practice internal rate of return (IRR) and others techniques and no one practice average rate of return and modified internal rate of return.

\section{Findings}

Thus, from the above results and discussion the findings are as follows:

- Various management accounting tools are in practice in Nepalese commercial banks.

- Maximum Nepalese commercial banks use more than one management accounting tools. Per Nepalese commercial bank uses five management accounting tools on an average.

- Management accounting is important to Nepalese commercial banks' management for planning, evaluating, controlling and decision making.

- There are various problems in practicing management accounting tools in Nepalese commercial banks such as lack of expertise, lack of information about tools, lack of top management's committee, accounting provisions of NRB, tax law compliances, high cost and so on. 


\section{Conclusion}

The basic purpose of this study is to analyze the management accounting practice in Nepalese commercial banks. The study shows that the management accounting practices like ratio analysis, capital budgeting, activity-based budgeting, and break-even analysis are widely used in Nepalese commercial banks. Similarly cost segregation, cash flow analysis, zero based budgeting, pricing decision and responsibility accounting are least in practice and standard costing is not in practice in Nepalese commercial banks. Out of various management accounting tools ratio analysis is used by maximum Nepalese commercial banks (100\%). Cash flow statement, break even analysis, activity based budgeting and capital budgeting are used by $67 \%$ banks. Cost segregation in to fixed and variable, responsibility accounting, and pricing decision are use by $33 \%$ banks. Zero based budgeting is used only by $17 \%$ banks. Each Nepalese commercial bank uses five management accounting tools on an average. Nepalese commercial banks prepare budget using various basis and maximum Nepalese commercial banks (83\%) prepare budget on the basis of actual expenses of previous year. Nepalese commercial banks prepare operational budget, overall master budget and annual budget only. $83 \%$ banks prepare annual budget, 50\% banks prepare overall master budget and $17 \%$ banks prepare operational budget. Nepalese commercial banks practice PBP, NPV, IRR and others capital budgeting techniques. Maximum banks (67\%) use NPV, 33\% banks use PBP, 17\% banks use IRR and 17\% banks use others techniques. The study concluded that various management accounting tools are in practice in Nepalese commercial banks and each Nepalese commercial bank uses more than one tools.

\section{References}

Alnesafi, A. (2018). Examining cost accounting systems practices in commercial banks:

evidence from Kuwait. Academy of accounting and financial studies journal, 22(4). www.abacadmies.org/articles/examining-cost-accounting

Ameen, A. M., Ahmed, M. F. and Abd Hafez, M. A. (2018). The impact of management accounting and how it can be implemented into the Organizational culture. Dutch journal of finance and management, 2(1), 02. https://doi.org/10.20897/djfm/91582

Ashfaq, K., Younas, S., \& Usman, M. (2014). Traditional Vs. Contemporary management accounting practices and its role and usage across business life 
cycle stages: evidence from Pakistani financial sector. International journal of academic research in accounting, Finance and management sciences, 4(4), 104-125. http://dx.doi.org/10.6007/IJARAFMS/v4-i4/1285

Gnawali, A. (2017). Management accounting system practice in Nepalese commercial banks. International journal of advanced research and publications, 1(5), 7276. http://www.ijarp.org/published-research-papers/nov2017/Management..

Gnawali, A. (2018). Accounting for Management Practices: A Holistic Perspective in Nepalese Commercial banks. International Journal of Research in Business Studies and Management, 5(4), 1-8. https://www.ijrbsm.org/papers/v5-i4/1.pdf kasasbeh, I. (2018). Problems of management accounting implementation: the case of balanced scorecard implementation within jordanian commercial banks. International journal of academic research in accounting, finance and management sciences, 8(2), 200-207. http://creativecommons.org/licences/by/4.0/legalcode

Kechema, T., et al. (2019). Barriers of accounting information system practice on the commercial bank of Ethiopia, Bale Robe branches. Annals Research, 4, 5-11. https://annalsor.com/wp-content/uploads/2019/10/219402.pd

Kingsley, A. N., \& Omoghene, H. P. (2018). Management accounting information and fraud control measures in commercial banks. Journal of economics and finance, 9(5), 48-53. http://www.iosrjournals.org/iosr-jef/papers/Vol9-Issue5/Version$3 / \mathrm{H}$..

Russo, A. (2014). Role and importance of managerial accounting into banking sector. Knowledge horizons - economics, 6(4), 57-62. http://orizonturi.ucdc.ro/arhiva/2014_khe_6_pdf4/postolache.pdf

Sunarni, C. W. (2013). Management accounting practices and the role of management accountant: evidence from manufacturing companies throughout yogyakarta, Indonesia. Review of integrative business \& economics research, 2(2), 616-626. https://www.academia.edu/28188571/Management_Accounting_Practices..

\section{Appendices}

\section{Appendix - A}

Practice of Management Accounting Tools in Commercial Banks in Nepal

\begin{tabular}{|c|c|c|c|c|}
\hline S. Management accounting & \multicolumn{4}{|c|}{ rcial banks } \\
\hline N & HBL PBL & SCB & NBBL & \\
\hline
\end{tabular}




\begin{tabular}{|c|c|c|c|c|c|c|c|c|}
\hline 1 & $\begin{array}{l}\text { Cost segregation in to fixed } \\
\text { and variable }\end{array}$ & 1 & 1 & - & - & - & - & 2 \\
\hline 2 & Responsibility accounting & - & - & - & - & 1 & 1 & 2 \\
\hline 3 & Standard costing & - & - & - & - & - & - & 0 \\
\hline 4 & Cash flow statement & 1 & 1 & - & 1 & - & 1 & 4 \\
\hline 5 & Break even analysis & 1 & 1 & 1 & 1 & - & - & 4 \\
\hline 6 & Pricing decision & - & 1 & - & 1 & - & - & 2 \\
\hline 7 & Activity based budgeting & - & 1 & 1 & 1 & 1 & - & 4 \\
\hline 8 & Zero based budgeting & - & 1 & - & - & - & - & 1 \\
\hline 9 & Capital budgeting & 1 & 1 & 1 & 1 & - & - & 4 \\
\hline \multirow[t]{2}{*}{10} & Ratio analysis & 1 & 1 & 1 & 1 & 1 & 1 & 6 \\
\hline & Total & 5 & 8 & 4 & 6 & 3 & 3 & 29 \\
\hline
\end{tabular}

Practice: (1), Not practice: (-)

\section{Appendix - B}

Basis for Preparation of Budget in Nepalese Commercial Banks

\begin{tabular}{|c|c|c|c|c|c|c|c|c|}
\hline \multirow{2}{*}{$\begin{array}{l}\text { S. } \\
\text { N. }\end{array}$} & \multirow{2}{*}{$\begin{array}{l}\text { Base for budget } \\
\text { preparation }\end{array}$} & \multicolumn{7}{|c|}{ Commercial banks } \\
\hline & & HBL & PBL & SCB & NBBL & EBL & SBIBL & Total \\
\hline 1 & $\begin{array}{l}\text { Actual expenses of } \\
\text { previous year }\end{array}$ & 1 & 1 & 1 & 1 & 1 & - & 5 \\
\hline 2 & Past budget & - & - & - & - & 1 & 1 & 2 \\
\hline 3 & Activity based budgeting & - & 1 & 1 & 1 & 1 & - & 4 \\
\hline 4 & Zero based budgeting & - & 1 & - & - & - & - & 1 \\
\hline 5 & Other (if any) & - & - & - & - & - & - & - \\
\hline & Total & 1 & 3 & 2 & 2 & 3 & 1 & 12 \\
\hline
\end{tabular}

Practice: (1), Not practice: (-)

\section{Appendix- C}

Types of Budget Practice in Nepalese Commercial Bank 


\begin{tabular}{lllcccccc}
\hline S. & \multicolumn{1}{c}{ Types of budget } & \multicolumn{7}{c}{ Commercial banks } \\
N. & & HBL & PBL & SCB & NBBL & EBL & SBIBL & Total \\
\hline 1 & Cash budget & - & - & - & - & - & - & - \\
2 & Operational budget only & - & - & 1 & - & - & - & 1 \\
3 & Overall master budget & - & 1 & 1 & 1 & - & - & 3 \\
4 & Long term budget & - & - & - & - & - & - & - \\
5 & Annual budget & 1 & 1 & 1 & - & 1 & 1 & 5 \\
6 & Others & - & - & - & - & - & - & - \\
& & 1 & 2 & 3 & 1 & 1 & 1 & 9 \\
\hline
\end{tabular}

Practice: (1), Not practice: (-)

\section{Appendix- D}

Capital Budgeting/Long Term Investment Decision Techniques Practice in Nepalese Commercial Banks.

\begin{tabular}{|c|c|c|c|c|c|c|c|c|}
\hline \multirow[t]{2}{*}{ S.N. } & \multirow{2}{*}{$\begin{array}{l}\text { Capital budgeting } \\
\text { techniques }\end{array}$} & \multicolumn{7}{|c|}{ Commercial banks } \\
\hline & & HBL & PBL & $\mathrm{SCB}$ & NBBL & EBL & SBIBL & Total \\
\hline 1 & Payback period (PBP) & 1 & - & 1 & - & - & - & 2 \\
\hline 2 & $\begin{array}{l}\text { Average rate of return } \\
(\mathrm{ARR})\end{array}$ & - & - & - & - & - & - & - \\
\hline 3 & Net present value (NPV) & 1 & 1 & 1 & 1 & - & - & 4 \\
\hline 4 & $\begin{array}{l}\text { Internal rate of return } \\
\text { (IRR) }\end{array}$ & - & 1 & - & - & - & - & 1 \\
\hline 5 & Profitability index (PI) & - & - & - & - & - & - & - \\
\hline 6 & $\begin{array}{l}\text { Modified internal rate of } \\
\text { return }\end{array}$ & - & - & - & - & - & - & - \\
\hline \multirow[t]{2}{*}{7} & Other techniques & - & - & - & - & - & 1 & 1 \\
\hline & Total & 2 & 2 & 2 & 1 & - & 1 & 8 \\
\hline
\end{tabular}

Practice: (1), Not practice: (-). 